\title{
Bio-Based Composites from Industrial By-products and Wastes as Raw Materials
}

\author{
Roxana Dinu ${ }^{1} \&$ Alice Mija $^{1}$ \\ ${ }^{1}$ University Côte d'Azur, Institute of Chemistry of Nice, UMR CNRS 7272, 06108 Nice Cedex 02, France \\ Correspondence: Alice Mija, University Côte d'Azur, Institute of Chemistry of Nice, UMR CNRS 7272, 06108 \\ Nice Cedex 02, France. Tel: +33 625904558 E-mail: Alice.Mija@unice.fr
}

Received: February 22, 2020

Accepted: March 10, 2020

Online Published: April 9, 2020

doi:10.5539/jmsr.v9n1p29

URL: https://doi.org/10.5539/jmsr.v9n2p29

\begin{abstract}
Innovative bio-based composites combining humins as biorefinery by-product with keratin or lignin as wastes or industrial side-products were developed. The bio-composites were prepared using three types of matrix formulations allowing the synthesis of elastic to rigid thermosets. These matrices were combined with chicken feathers powder, non-woven chicken feathers mat or lignin to produce bio-composites. A maximum quantity of bio-fillers was used, around $10 \mathrm{wt} . \%$. The effect of the bio-fillers on the matrix's crosslinking was studied by rheology and DSC. Then, the obtained materials were analyzed by TGA, DMA, tensile tests, water absorption and SEM. The results show a very good compatibility of the humins matrix with the bio-fillers, without any preliminary modification of the matrix, that is exceptional for the point of view of a composite. The overall performances of the neat matrix were maintained or improved through the composites. Therefore, bio-composites with potentially interesting thermal and mechanical properties have been synthesized. In the case of the elastic ductile matrix the Young's modulus value was improved from 1 to $22 \mathrm{MPa}$, while for the rigid matrix the increase was from 106 to 443 or $667 \mathrm{MPa}$, in the case of composites with non-woven chicken feathers mat or lignin. To our knowledge this is the first study combining humins matrix with keratin. The obtained bio-composites are sustainable materials linked via the used raw materials to the circular economy and biomass valorization.
\end{abstract}

Keywords: humins, keratin, chicken feathers, lignin, bio-composites

\section{Introduction}

One of the main problems faced by humanity currently and in the future is the intense pollution of the environment due to the production and use of materials based on fossil derivatives but also due to the increasing amount of industrial wastes (Brostow \& Hagg Lobland, 2017). The need to significantly reduce the environmental pollution has led to the investigation and development of new materials from renewable resources. Proteins are biopolymers with a big potential to develop materials since they are biodegradable, renewable, inexpensive and especially abundant (Poole, Church, \& Huson, 2009). An important source of protein is the chicken feathers, a by-product from the poultry industry (Garrido, Peñalba, de la Caba, \& Guerrero, 2019).

Since ancient times, people have been using birds for food, falconry, in ritual, for aviary specimens and pets. Historical sources prove that bird feathers were used for preparing arrows, while the archaeological data present evidence for the use of wild birds (e.g., hooded crow) in funeral ceremonies (Gorobets \& Kovalchuk, 2017). According to the biannual report on global food markets made by Food and Agriculture Organization of the United Nations, the global production of poultry meat was estimated at 128.4 million tons in 2019 (FAO, 2019). Given that feathers represent about 5-7\% of the body weight of an adult chicken (A. L. Martínez-Hernández, Carlos Velasco-Santos, De-Icaza, \& Castano, 2007; McLelland, 1990), about 9 million tons of feathers are annually produced worldwide. The chicken feathers are composed of $91 \%$ keratin, $8 \%$ water and $1 \%$ fats (Bansal \& Singh, 2016; Ana Laura Martínez-Hernández \& Carlos Velasco-Santos, 2012; Reddy \& Yang, 2007; Tesfaye, Sithole, Ramjugernath, \& Chunilall, 2017). Only a small part of chicken feathers is converted in low nutritional animal feed. The largest amount of feathers is deposited in landfills or burned, leading to environmental pollution, and moreover to the loss of a very rich resource of high protein raw material.

For birds, feathers play an important role in flight, protection, heat retention, waterproofing, etc. All of these functions are performed with the help of some types of feathers such as contour feather, semiplume, filoplume, chick down and bristle feather, which are found in different parts of the body and have distinct role and 
structures.(G \& VK, 2016; Seawright, Marcicano, \& Navarrete, 2013) Feathers present a complex hierarchical branched structure where rachis is the primary structure, barbs are the secondary and barbules the tertiary branches structure.(Ana Laura Martínez-Hernández \& Carlos Velasco-Santos, 2012) In the cross-section of the rachis and the barb one can see the presence of a honeycomb structure.(Ana Laura Martínez-Hernández \& Carlos VelascoSantos, 2012; Sah, Goel, \& Omre, 2015; Tesfaye et al., 2017) According to Reddy and Yang(Reddy \& Yang, 2007) this honeycomb structure act as an air and heat insulator, providing high resistance to compressibility and making the fibers very light in weight, having a very low-density $\left(0.8 \mathrm{~g} / \mathrm{cm}^{3}\right)$ compared with the wool $\left(1.3 \mathrm{~g} / \mathrm{cm}^{3}\right)$ and cellulose fibers $\left(1.5 \mathrm{~g} / \mathrm{cm}^{3}\right)$. (Barone \& Schmidt, 2005; Lewin, 2007)

Chicken feathers being composed from $91 \%$ protein (keratin), represent one of the main sources of keratin. Keratin is a natural and small protein, uniform in size with a molecular weight around $10 \mathrm{kDa}(10500 \mathrm{Da})$ (Khosa \& Ullah, 2013), consisting of polypeptide chains obtained by the condensation of different amino acids, their content on feathers depending on the environment, food and breed.(Ana Laura Martínez-Hernández \& Carlos Velasco-Santos, 2012) One of the most important keratin's polypeptide is the cysteine which is present in a large quantity.(Wallenberger \& Weston, 2004) The cysteine contains thiol groups which interact to form disulfide bonds therefore contributing to the semi-crystalline structure of feather keratin and it is hydrophobic. The second largest amino acid in chicken feathers is the serine which contains the $-\mathrm{OH}$ groups making the feathers hydrophilic. Chicken feather fibers have both hydrophobic and hydrophilic character and approximately the ratio is 60:40 percentages.(Pauling, Corey, \& Branson, 1951; Saravanan \& Dhurai, 2012; Staron, Banach, \& Kowalski, 2011; Wallenberger \& Weston, 2004) Based on X-ray diffraction, keratins can be classified into $\alpha$-pattern, $\beta$-pattern, feather-pattern and amorphous pattern.(Astbury \& Street, 1931; R.D.B. Fraser, Macrae, Parry, \& Suzuki, 1969; R D B Fraser \& MacRae, 1973) The feather pattern has been considered as $\beta$-pattern since both patterns show the same characteristic reflections.(R.D. Bruce Fraser \& Parry, 2011) Usually, keratin classification are used the two regular secondary structures $\alpha$-helix and $\beta$-sheet. The $\alpha$-keratins are found in the soft tissues such as sheep wool, skin and hair while $\beta$-keratins are present in hard tissues proteins of bird feathers, fish scales, nails and others (Sharma \& Gupta, 2016). The most representative $\alpha$-keratin material is the wool while the feathers are typical for $\beta$-keratin materials (B. Wang, Yang, McKittrick, \& Meyers, 2016).

Considering the large amount of keratin present in chicken feathers, these represent a valuable resource with countless potential applications in cosmetics, biomedical applications (J. Wang, Hao, Luo, Yang, \& Wang, 2016; $\mathrm{Xu}, \mathrm{Cai}, \mathrm{Xu}, \&$ Yang, 2014), thermoplastics and packaging materials(Reddy, 2015; Reddy, Chen, \& Yang, 2013; Shi, Reddy, Hou, \& Yang, 2014), thermosets, composites for different sectors of industry (construction, automobile, etc.), biofertilizers(Gurav \& Jadhav, 2013; Hadas \& Kautsky, 1994), coatings, etc. The good properties but also the abundance of the chicken feathers made them more and more interesting and used by the researchers in the development of new green materials able to replace those based on fossil derivatives (Donato \& Mija, 2019). For example, Yin et al. (2013) reported the fabrication of porous keratin films using keratin from chicken feathers for controlled drug delivery systems. Firstly, a stable and homogeneous keratin was extracted from chicken feathers using Shindai method, with a yield of $93 \%$ and a molecular weight of around $20 \mathrm{kDa}$. Thereafter, the obtained chicken feather keratin was mixed with glycerol developing films with controlled thickness (by varying the volume of the keratin dispersion) and good mechanical properties. These keratin-based films were $\mathrm{pH}$-responsive, showing a controllable drug-releasing behavior making them an attractive candidate for application in the biomedical field. Song et al. ( 2014) have developed chicken/gelatin composite protein films with clove oil, with potential application in the active packaging for smoked salmon. The mechanical properties of the prepared composite films were investigated showing that the tensile strength and elongation at break significantly increased with the increase of the gelatin content. Also, the incorporation of $1.5 \%$ clove oil into the film improved the antimicrobial properties of the composite film and its mechanical properties were not affected, being considered a potential active packaging material for smoked salmon preservation Yang and Reddy (2013) reinforced the high-density polyethylene (HDPE) from plastic bags with chicken feathers to develop composites in an effort to add value and to reduce the amount of the plastics and feathers disposed in landfills. The authors created sandwich structures with layers of plastic and feathers varying the proportions (w/w) from 40/60 to 70/30. The effect of the ratio of feathers in the composite and the influence of the manufacturing parameters on the mechanical properties of the final materials have been studied. It was found that incorporating feathers as reinforcement for HDPE at the optimum conditions $\left(182^{\circ} \mathrm{C}\right.$ and $\left.2 \mathrm{~min}\right)$ substantially improved the flexural strength, tensile modulus and sound absorption than 100\% HDPE. The authors showed by this research that discarded plastic bags and chicken feathers can be used as valuable products in the composites production for different industrial sectors. In order to replace the non-renewable composite materials, Huda and Yang (2008) proposed to develop composites from ground chicken quill and polypropylene. They investigated the mechanical and acoustical properties of this kind of composites and compared them with jute-polypropylene composites, concluding that the 
ground quill composites can be an ideal candidate for acoustic panels or headliner substrates. Hong and Wool (2005) developed a novel bio-based composite material from soybean oils and keratin feather fibers. The authors used acrylated epoxidized soybean oil and soybean oil pentaerythritol glyceride maleates as liquid molding resins and two different types of non-woven keratin fiber mats, obtaining environmentally friendly, low-cost composites, suitable for electronic as well as automotive and aeronautical applications. Following the studies, it was observed that the literature deals with applications of other chicken products also, not only of chicken feathers. For instance, Rivera et al. (1999) used the eggshells in a phosphate solution at an elevated temperature, developing a new procedure for the synthesis of porous hydroxyapatite.

Another abundant renewable resource in nature is the lignocellulosic biomass composed manly from three principal components i.e. cellulose (35-50\%), hemicellulose (20-35\%) and lignin (10-25\%) (Delidovich et al., 2016). Lignin is a phenolic complex macromolecule with an irregular structure affected by various factors like biomass sources, fractionation's methods, and fractionation's severity (Ponnusamy et al., 2019; H. Wang, Pu, Ragauskas, \& Yang, 2019). Lignin is a three-dimensional network composed mainly of three types of phenylpropanoid units as coniferyl, sinapyl, and p-coumaryl alcohols (Abreu, Nascimento, \& Maria, 1999). This heterogeneous biopolymer is a by-product of biorefineries that process plant biomass to produce fuels and chemicals, but also a waste of the pulp and paper industries. Generally, most of the lignins are burned to generate heat and electricity, but has also gained increased attention in other application areas such as pharmacology (Spiridon, 2018), as lignin nanostructure for possible applications in UV protection and biomedical applications (Mishra \& Ekielski, 2019), or bioplastic and bio-composites (J. Yang, Ching, \& Chuah, 2019). For example, Diop et al. (2015) reported the development of the composites with around $20 \%$ lignin used as filler in a low-density polyethylene matrix, obtaining an increment of the mechanical properties of the materials. Composites were developed by Yin et al. (2012) by blending the lignin with an epoxy-polyamine resin and using a hot press molding process. They studied the effect of molding's temperature and pressure on the mechanical properties and microstructure of the lignin/epoxy resin composites. After these studies, the authors noticed that the properties of the materials initially increased, then decreased, the excessively high applied temperature causing the degradation of the composite that become brittle, the optimal temperature being around $130{ }^{\circ} \mathrm{C}$. Therefore, according to literature studies, the lignin begun to show great interest, being extensively researched as an possible alternative to petrochemical-based reinforcements (Feghali et al., 2018; Thakur, Thakur, Raghavan, \& Kessler, 2014).

Another industrial side-product generated by the processing and valorization of lignocellulose is a black and viscous compound called humins. Humins are polyaromatic condensed structures derived from sugar conversion processes with a molecular structure unknown, which is influenced by the type of feedstock and the processing parameters (Hu, Lievens, \& Li, 2012; Van Zandvoort et al., 2013). These carbon-rich agglomerate particles contain acid, ketone, alcohol, aldehyde groups and are composed of approximately 50-66 wt.\% C and 29-46 wt.\% O, the rest being $\mathrm{H}(\mathrm{Hu}$, Lievens, Larcher, \& $\mathrm{Li}, 2011)$. In recent years, the valorization of this by-product derived from biorefinery into high value products has shown a growing interest for researchers. The humins' potential to generate materials has been tested, thus obtaining thermosets furanic resins and composites (Pin et al., 2014; Pin, Guigo, Vincent, Sbirrazzuoli, \& Mija, 2015) or porous materials (Kang et al., 2018; Patent No. WO 2017/074183 A1, 2017; Tosi et al., 2018), but this by-product is not yet sufficiently valued and exploited.

In this study, humins-based resins were combined for the first time with bio-fillers like chicken feathers powder, non-woven chicken feathers mat or lignin in order to develop sustainable bio-composites with potential industrial applicability. The influence of these natural fillers on humins-based resins reactivity was analyzed by differential scanning calorimetry (DSC) and rheometry. The morphology of the bio-composites was investigated by scanning electronic microscopy (SEM). Then, the thermomechanical properties were analyzed by thermogravimetric analysis (TGA), dynamic mechanical analysis (DMA), Shore hardness test and tensile tests. The materials' water absorption was also investigated.

\section{Method}

\subsection{Materials}

The main component of the elaborated resins is represented by the humins, an industrial polymeric by-product, produced and supplied by Avantium Chemicals at their Pilot Plant in Geleen, The Netherlands. To obtain thermoset resins, humins were mixed with comonomers like poly (ethylene glycol) diglycidyl ether (PEGDE) and glycerol diglycidyl ether (GDE). The N, N-Dimethylbenzylamine (BDMA) was used as initiator. Except the humins, all the chemicals were purchased from Sigma-Aldrich and used as received. The protocol of resins' preparation was described elsewhere (Dinu \& Mija, 2019). 
To develop composites, the humins-based mixtures were combined with chicken feathers (from food industry) or lignin (from biorefineries) used as structural elements for reinforcing the polymeric matrix. The fractioned Kraft lignin was supplied by VTT Technical Research Centre (Finland) as a brown powder with a weak odor, a pH ranged between 2.5-7 and sulfur content 1-3\%. This product is not soluble under acidic condition, but is soluble under alkaline condition, in DMSO. The chicken feathers were produced and sanitized by Grupo SADA (Spain) then grinded by Institute of Biopolymers and Chemical Fibers (IBWCh) (Poland). Two types of chicken feathers were provided by IBWCh: grinded feathers (powder) and non-woven fibers. Chicken feather powder (CFP) were obtained by IBWCh using a Planetary Ball Mill (Type: XQM-16 A) to achieve a high degree of fragmentation $(10-250 \mu \mathrm{m})$. The non-woven chicken feathers mat (CFM) were produced by IBWCh by combining $90 \mathrm{wt} \%$ chicken feathers fibers with $10 \mathrm{wt} . \%$ bicomponent synthetic fibers, core PET, Type T25 Biko flat 2.2 dtex, semimatte, used in the production of wet-laid non-woven (Wrześniewska-Tosik, Szadkowski, Marcinkowska, \& Pałczyńska, 2012).

\subsubsection{Samples preparation.}

The humins-based resins were developed as previously described (Dinu \& Mija, 2019) by mixing the required amount of humins with the comonomers (PEGDE and GDE) and the initiator (BDMA), thus obtaining three kinds of thermosets ranging from elastic to the rigid. For an easier identification of the resins, acronyms have been used depending on the composition as follows: Humins 55\%/ PEGDE 40\%/ BDMA 5\%=HP40B5 for the flexible resin, Humins 55\%/ PEGDE 20\%/ GDE 20\%/ BDMA 5\% = HP20G20B5 for the semi-elastic one and Humins 55\%/ GDE $40 \%$ / BDMA 5\%= HG40B5 for the rigid one. Bio-composites with $10 \mathrm{wt} \%$ of chicken feathers powder (CFP) or with $10 \mathrm{wt} . \%$ lignin (L) were made by mechanically mixing the fresh resins formulations with the biofiller. The mixtures of resin/chicken feather powder or resin/lignin were poured in a rectangular metallic mold $\left(150 \times 150 \times 4 \mathrm{~mm}^{3}\right)$ and cured using a heated press (Bench Top Manually Heated Mini CH 5420 Model Press, Carver Inc.) for 4 hours at $130{ }^{\circ} \mathrm{C}$ and 2 metric tons pressure. The composites with non-woven chicken feathers mat (CFM) were prepared using a hand lay-up technique. Composite panels with non-woven chicken feathers fibers were consolidated from 3 plies of mats; the number of plies was selected to achieve a thickness of approximately $0.4 \mathrm{~cm}$. In the rectangular metallic mold, a layer of resin was poured. Thereafter, the first nonwoven mat was laid in the mold being covered with a second layer of resin. The composites were placed between the platens of the Carver press and cured during 4 hours at $130{ }^{\circ} \mathrm{C}$ and 2 metric tons pressure. After curing under compression, the samples were cooled and removed from the metallic molds. Following the calculation, it was determined that the 2 plies of mats represent $12 \mathrm{wt} . \%$ of the total weight of the CF mat in the composite. The acronyms of the composites were reported as the "resin name" then complementing with the initials of the filler. The chicken feather powder was abbreviated with "CFP", the lignin with "L" and the chicken feathers mat with "CFM". So, if the material was developed combining the HG40B5 resin with $10 \mathrm{wt} \%$ CFP, the final composite was called HG40B5-10CFP.

\subsection{Experimental techniques}

\subsubsection{Density of the composites}

The ISO 9427 standard was used to evaluate the density of the humins-based resins and composites. Five rectangular samples $\left(50 \times 8 \times 4 \mathrm{~mm}^{3}\right)$ of each specimen with a known volume were weighed. The density of the samples was then calculated as the ratio of the mass to volume.

\subsubsection{Differential Scanning Calorimetry (DSC)}

A DSC 3 Mettler-Toledo apparatus controlled by STARe Software developed by Mettler-Toledo was used. The calibration of the instrument heat flow and temperature was done using water, indium and zinc standards. Samples of 10-15 mg were placed into $100 \mu \mathrm{L}$ aluminum crucibles. The crosslinking reaction were studied under nonisothermal conditions, at a heating rate of $10{ }^{\circ} \mathrm{C} \cdot \mathrm{min}^{-1}$ under air flow $\left(150 \mathrm{~mL} \cdot \mathrm{min}^{-1}\right)$, over a temperature range of $25-250{ }^{\circ} \mathrm{C}$. The reactions' enthalpies of humins-resins and fillers mixtures were normalized to the mass of resin in the analyzed compositions. After the curing of the materials, the DSC was also used to determine the first-order transitions like eventual residual exothermy or the second-order transitions like the glass transitions of the obtained materials and composites. Samples of crosslinked humins-based composites with the mass between 9-12 mg were scanned at $10{ }^{\circ} \mathrm{C} \mathrm{min}{ }^{-1}$ under air flow $\left(150 \mathrm{~mL} \cdot \mathrm{min}^{-1}\right)$ from $-50{ }^{\circ} \mathrm{C}$ to $180{ }^{\circ} \mathrm{C}$. 


\subsubsection{Rheometry}

To determine the influence of the bio-fillers on the crosslinking process different amounts of chicken feathers powder or lignin were added to the reactive resins mixtures and then analyzed by rheometry. Rheological measurements were conducted under nitrogen atmosphere in an Anton Paar MCR-302 rheometer using disposable plate-plate geometries ( $25 \mathrm{~mm}$ diameter and $1 \mathrm{~mm}$ gap). The measurements were made at a scan rate of $0.2^{\circ} \mathrm{C} \cdot \mathrm{min}^{-}$ ${ }^{1}$ from $50{ }^{\circ} \mathrm{C}$ to $200{ }^{\circ} \mathrm{C}$. To determine the storage modulus (G') and loss modulus (G') but also the complex viscosity of the samples, the measurements were conducted by oscillatory shear experiments with an angular frequency of $10 \mathrm{rad}^{-1} \mathrm{~s}^{-1}$ and a deformation of $0.2 \%$.

\subsubsection{Thermogravimetric analysis (TGA)}

Thermal stability of humins-based composites was studied using thermogravimetric analysis. The mass loss and its derivative as a function of temperature for the cured samples were evaluated using a TGA 2 Mettler-Toledo over a temperature range of $25{ }^{\circ} \mathrm{C}-1000{ }^{\circ} \mathrm{C}$ under oxidative atmosphere $\left(150 \mathrm{~mL} \cdot \mathrm{min}^{-1}\right)$ and a heating rate of $10^{\circ} \mathrm{C} \cdot \mathrm{min}^{-1}$. Samples with the mass between $10-15 \mathrm{mg}$ were placed into $70 \mu \mathrm{L}$ alumina pans and analyzed three times for average calculation.

\subsubsection{Dynamic mechanical analysis (DMA)}

Mechanical properties of the composites (storage modulus E', loss modulus E', and damping factor $\tan \delta=\mathrm{E}$ '/E') were analyzed in a DMA 1 by Mettler-Toledo using a three-point bending fixture at an oscillatory frequency of $1.0 \mathrm{~Hz}$ and an amplitude of $20 \mu \mathrm{m}$. The rectangular samples with the dimensions of $48 \times 8 \times 4 \mathrm{~mm}^{3}$ (length $\times$ width $\times$ thickness) were analyzed 3 times and the values averaged. The temperature ramp was selected from -150 to $180^{\circ} \mathrm{C}$ at a heating rate of $3{ }^{\circ} \mathrm{C} \cdot \mathrm{min}^{-1}$ under nitrogen atmosphere.

\subsubsection{Tensile testing}

The tensile properties of the materials were determinate by a universal testing machine Instron, Norwood, MA, USA model 3365, controlled by BlueHill Lite software developed by Instron (Norwood, MA, USA). For the test, a crosshead speed of $10 \mathrm{~mm} \cdot \mathrm{min}^{-1}$ was used on samples of dimension $75 \times 10 \times 4 \mathrm{~mm}^{3}$ (length $\times$ width $\times$ thickness).

Ten samples for each formulation were tested in order to evaluate the average calculations of mechanical properties like Young's modulus, tensile strength, and elongation at break.

\subsubsection{Water absorption}

Water absorption of the humins-based resins and composites were determined by immersion of the samples in distilled water at $25^{\circ} \mathrm{C}$ in accordance with the ASTM D570 standard test method (ASTM-D570, 1998). In the first step, the rectangular test specimens $\left(50 \times 8 \times 4 \mathrm{~mm}^{3}\right)$ were dried in an oven at $50^{\circ} \mathrm{C}$ for $24 \mathrm{~h}$, after cooled in a desiccator and immediately weighed. Then, the specimens were immersed in distilled water and maintained at room temperature for 24 hours. At the end of the $24 \mathrm{~h}$, the samples were removed from water and all the surface water wiped off with a dry cloth. Thereafter, the so prepared specimens were weighed and immediately immersed again in distilled water and then the percentage of absorbed water (\%WA) was calculated.

\subsubsection{Scanning electron microscopy (SEM)}

The morphology of fracture surfaces of the bio-composites but also the compatibility between the humins based matrix and the filler were investigated by scanning electron microscopy (SEM). The sample were analyzed using a Tescan Vega XMU SEM at an accelerating voltage of $5 \mathrm{kV}$. All samples were coated with platinum prior to observations.

\section{Results and Discusion}

\subsection{Reactivity study of the humins-based resins in presence of chicken feathers powder or lignin bio-fillers}

\subsubsection{Differential scanning calorimetry}

To identify the influence of the two bio-fillers on the thermal crosslinking of the humins based resins, the DSC analyses for reactive humins formulations and their mixtures with chicken feathers powder and lignin were made and compared. Figure 1 highlights the changes taking place during crosslinking reactions.

The curing of all the samples is observed as a large exothermic peak, sign of a complex reactivity, characteristic for the humins resin. We can observe also from Figure 1 that the onset of crosslinking is around $35-45^{\circ} \mathrm{C}$ and this value is more or less the same, whatever the system composition. This result could already translate that the presence of the bio-fillers didn't affect the curing initiation. The two bio-fillers could be considered, at this point, inert vis-à-vis of generation of active species that initiate the crosslinking. According to the data summarized in 
the Table 1, it can be observed that for the HP40B5 formulation, the maximum temperatures of reaction of mixtures with chicken feathers powder or lignin decrease compared to that of the neat resins.
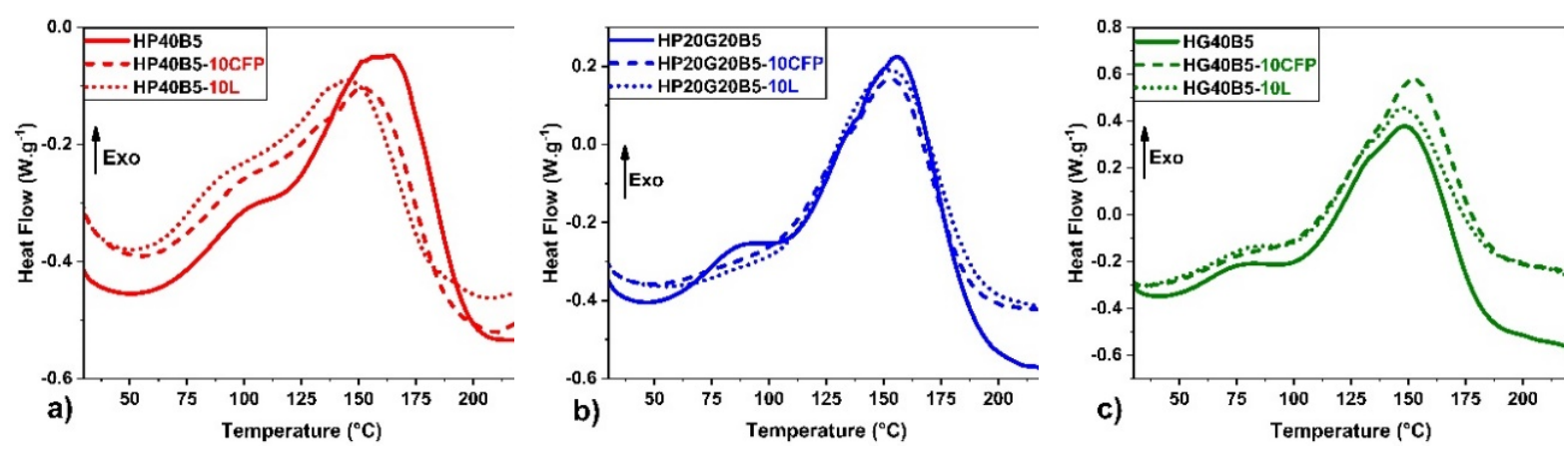

Figure 1. DSC analysis for uncured resins and their mixtures with $10 \mathrm{wt} . \%$ chicken feathers powder (10CFP) or 10 wt.\% lignin (10L): a) HP40B5, b) HP20G20B5, c) HG40B5

Table 1. DSC analyses for curing of three reactive systems and their mixtures with chicken feathers powder or lignin

\begin{tabular}{|c|c|c|c|c|c|c|}
\hline \multirow[t]{2}{*}{ Sample } & \multicolumn{3}{|c|}{$\begin{array}{c}\text { Reaction } \mathbf{T}_{\max } \text { (interval) } \\
{\left[{ }^{\circ} \mathbf{C}\right]}\end{array}$} & \multicolumn{3}{|c|}{$\begin{array}{c}\text { Enthalpy of reaction } \\
{\left[\mathrm{J} . \mathrm{g}^{-1}\right]}\end{array}$} \\
\hline & Neat Resin & Mix Resin-10CFP & Mix Resin-10L & Neat Resin & Mix Resin- 10CFP & Mix Resin- 10L \\
\hline HP40B5 & $\begin{array}{c}164 \pm 1 \\
(42-215)\end{array}$ & $\begin{array}{c}152 \pm 2 \\
(40-210)\end{array}$ & $\begin{array}{c}146 \pm 1 \\
(45-206)\end{array}$ & $212 \pm 3$ & $192 \pm 4$ & $160 \pm 4$ \\
\hline HP20G20B5 & $\begin{array}{c}157 \pm 2 \\
(40-230)\end{array}$ & $\begin{array}{c}153 \pm 1 \\
(40-215)\end{array}$ & $\begin{array}{c}153 \pm 1 \\
(48-217)\end{array}$ & $319 \pm 2$ & $228 \pm 3$ & $230 \pm 3$ \\
\hline HG40B5 & $\begin{array}{c}148 \pm 1 \\
(38-228)\end{array}$ & $\begin{array}{c}152 \pm 1 \\
(36-215)\end{array}$ & $\begin{array}{c}149 \pm 1 \\
(33-208)\end{array}$ & $333 \pm 4$ & $313 \pm 4$ & $253 \pm 3$ \\
\hline
\end{tabular}

In the HP20G20B5 system, we can observe that the $\mathrm{T}_{\max }$ of curing is not affected by the filler and the $\mathrm{T}_{\max }$ values between the resin and the mixture resin-filler are almost the same. The area under the exothermic crosslinking peak was integrated in order to obtain the heat of cure $\left(\Delta \mathrm{H}_{\text {cure }}, \mathrm{J}_{\mathrm{g}} \mathrm{g}^{-1}\right)$ of each formulation. In all the cases we can notice a decrease in the value of the reaction enthalpy when the filler is added. For HP40B5 and HG40B5 systems, the enthalpy of crosslinking in presence of CFP shows a relatively small decrease $\left(\sim 20 \mathrm{~J} \mathrm{J.g}^{-1}\right)$ compared to that of the neat resin, while the difference between the reactivity of resins and that of the mixtures with lignin is much higher $\left(\sim 90 \mathrm{J.g}^{-1}\right)$. This result translates that nor the CFP nor the lignin enter in reactions with the resins and they play the role of inert fillers. The decrease in enthalpy is higher in the presence of the lignin, perhaps due to the morphology of lignin powder that is formed by bigger particles that the CFP's one. For the HP20G20B5 formulations with the two bio-fillers the heat of cure is $\operatorname{similar}\left(\sim 230 \mathrm{~J} \mathrm{gg}^{-1}\right)$. However, is very difficult here to give a clear interpretation on the curing behavior since the humins crosslinking process is a very complex one, due to the complex composition of the neat humins. Moreover, this DSC study clearly shows that no chemical interaction between the CFP or L could be found with the humins resins. The allure of the DSC thermograms are very similar inside the same system. Nor the reaction onset, nor the end of reaction are affected by the presence of the biofillers. The $T_{\max }$ suffers some changes together with the reaction enthalpy that is the most affected by the presence of the fillers.

\subsubsection{Rheometry analysis during crosslinking}

Rheometry analysis was used to study the evolution of viscosity and of the viscoelastic properties during the crosslinking reaction of the three humins-based systems and of their mixtures with the bio-fillers. The Figure 2 gives the results of the evolution of moduli (G', G') and viscosity during curing of a selected system resins: the HG40B5 and its mixtures with the two bio-fillers. The influence of the filler's amount was also analyzed (Figure 1ESI). From the shape of the viscosity curves it can be seen the changes of the samples from a low-melting solid to a low viscosity liquid, thereafter to a gel, and at the end of the curing to a stiff solid. 

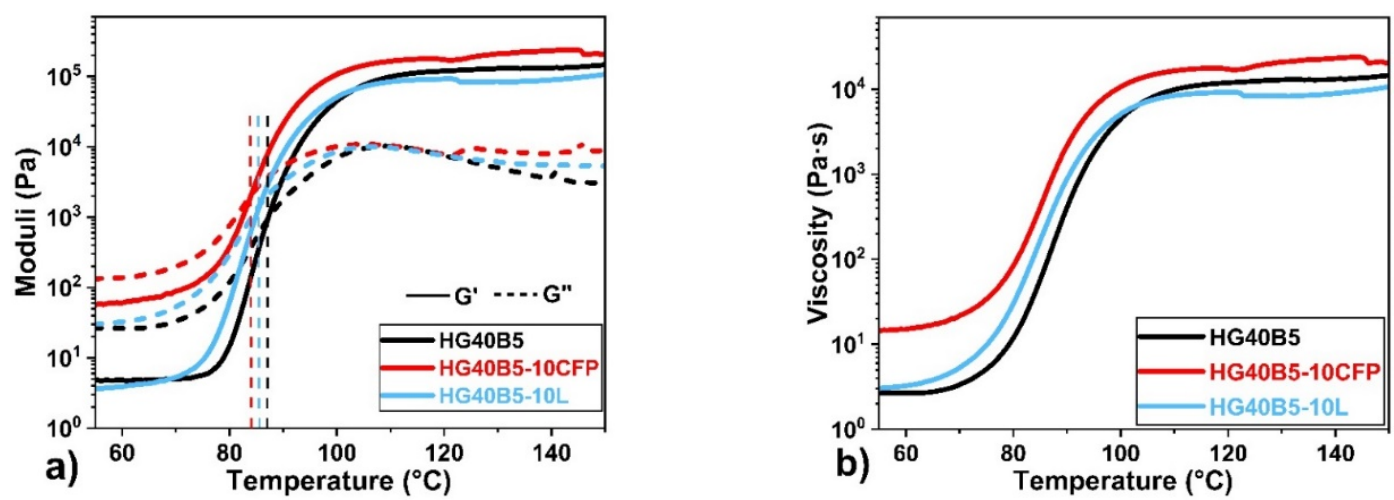

Figure 2. Rheology study of the unfilled HG40B5 curing system and their mixture with CFP and Lignin. Evolution of a) modulii and b) viscosity during heating from $50{ }^{\circ} \mathrm{C}$ to $200{ }^{\circ} \mathrm{C}$ at $0.2{ }^{\circ} \mathrm{C} \cdot \mathrm{min}^{-1}$. Comparison between unfilled, 10CFP and 10L filled resins

According with the data displayed in Figure 2 and Table 1ESI, we can notice that the fillers' nature and ratio influence the rheological behavior of the systems during the curing. Firstly, we can notice that the resin mixture has almost the same viscosity that the resin with $10 \mathrm{wt} . \% \mathrm{~L}$, both in the initial (unreacted) or final (crosslinked) state. This result is correlated with that of moduli, that are also very close for the resin and its mixture with the lignin. What we can observe is that the presence of the lignin provokes a small decrease, with some degrees, in the gelling point of the mixture. In contrast, the mixture with $10 \mathrm{wt} . \%$ CFP show a strong increase in the unreacted system's viscosity, with around a decade. This increase on viscosity could be correlated with the particle-particle interactions of CFP or by the interactions of the CFP particles with the resin, like hydrogen bonding between amino groups from keratin with oxygen based functional groups of the humins resins. The fact that the viscosity of the systems increases by the amount of the CFP (Figure 1ESI) could reinforce the first hypothesis by the thickening of the suspensions by particle-particle interactions. This behavior is also reflected in the increased values of the 10 wt.\% CFP system moduli compared with that of the neat resin. The sol-gel transition occurs at lower temperatures in this system that conduct to thermosets with higher stiffness.

If we corroborate the DSC and rheometry results, is somehow difficult to understand why the system with CFP has a higher reactivity, considering that the viscosity of this system is much higher than the neat resin. According with the literature, the filler effects on the chemo-rheology of thermosetting resins has not been studied extensively (Halley \& Mackay, 1996). Chirayil et al. (2014) studied the rheological changes during the crosslinking of an unsaturated polyester system and the influence of nanocellulose filler which was extracted from Helicteres isora plant using steam explosion technique. They found that the presence of nanocellulose filler influences the rheological behavior of the systems during the curing process and the gelation process is shifted to smaller values seeing it a clear tendency of cure acceleration in the presence of the filler.

A comparison of rheological behavior between the HG40B5 curing system and its mixtures with different amounts of CFP or lignin is represented in Figure 1ESI. It can be noticed that the viscosity and G' and G" moduli are significantly higher in the case of systems with CFP while for the materials with lignin the values remain similar to that of the unfilled resin.

\subsection{Physicochemical characterization of bio-composites}

\subsubsection{Thermogravimetric analysis (TGA)}

Thermogravimetric analyses (TGA) were carried out to determine the influence of the bio-fillers on the thermal stabilities of the cured materials as a function of temperature under oxidative atmosphere. The thermal stability of each resin is compared in Figure 3ESI with three types of composites: i) composites with $10 \mathrm{wt} . \%$ CFP, ii) composites with $10 \mathrm{wt} . \%$ Lignin and iii) composites with $12 \mathrm{wt} \%$ CFM. The temperature of degradation was considered at $5 \%$ of the weight loss of materials, the $\mathrm{T}_{5 \%}$ values being tabulated in Table 2 . The thermal stability stipulated in the literature for the chicken feathers fibers is between $220^{\circ} \mathrm{C}$ and $240{ }^{\circ} \mathrm{C}$ (Bessa et al., 2017; Cheung, Ho, Lau, Cardona, \& Hui, 2009). According to reported results (Aranberri, Montes, Azcune, Rekondo, \& Grande, 2018, 2017; Flores-Hernández et al., 2014; Pourjavaheri et al., 2017) it has been observed that the addition of chicken feathers as filler in a polymeric matrix decreases the thermal stability of the composites compared to the neat resin. Pourjavaheri et al. (2017) developed by solvent-casting method new bio-composites using thermoplastic 
poly(ether urethane) as matrix and chicken feather fibers (CFF) as reinforcement. The thermal stability of the composites developed with 30 and $60 \% \mathrm{w} / \mathrm{w}$ CFF was analyzed and compared with the neat resins, thus observing that the addition of the chicken feathers decreases the thermal stability of the final materials. If the $\mathrm{T}_{5 \%}$ of the neat resins is about $313{ }^{\circ} \mathrm{C}$, the addition of $30 \%$ CFF decreased the thermal stability of the final material with around $40{ }^{\circ} \mathrm{C}$, while the $\mathrm{T}_{5 \%}$ of the bio-composite with $60 \% \mathrm{CFF}$ was $\sim 249^{\circ} \mathrm{C}$. There are also studies in which the feathers improve the thermal stability of resins (Amieva et al., 2015; A.L. Martínez-Hernández et al., 2007) as in our case. It can be seen that the nature of the polymer matrix does not affect the thermal behavior trend of the composites. The presence of the CFP or CFM in the three humins formulations improve the thermal stability $\left(\mathrm{T}_{5 \%}\right)$ of the composites in a similar manner, while the addition of lignin in the polymer matrix provides a greater improvement in thermal stability compared to the composites with feathers. Following the thermogravimetric analyses it can be observed that the thermal stability of the bio-composites with CFP $\left(230-240{ }^{\circ} \mathrm{C}\right.$, depending of the resin nature $)$ is similar with that of the materials with $\mathrm{CFM}\left(235-243{ }^{\circ} \mathrm{C}\right)$, and for the composites with lignin the thermal stability is $\sim 240-250{ }^{\circ} \mathrm{C}$. These values indicate a good stability of the composites, being comparable to those already stipulated in the literature. For example, the thermal stability of the poly(urea-urethane)/chicken feathers biocomposites developed by Aranberri et al. (2018) is between $205-240{ }^{\circ} \mathrm{C}$ depending on the polymer/CF ratio.

The shape of thermogram curve of the polymer matrix is similar with that with $10 \mathrm{wt} \%$ lignin composites, presenting three main steps of degradation. The first degradation step of pyrolysis presents the largest mass loss of lignin composites, being around $50-60 \%$. Between $450-700{ }^{\circ} \mathrm{C}$ a second mass loss occur for systems under the air flow, with a lower mass loss compared to the first stage. Over $700{ }^{\circ} \mathrm{C}$ begins the complete degradation of the systems that takes place through the thermo-oxidation and carbonization reactions. The mechanism of thermal degradation of the composites with chicken feathers (10 wt.\% CFP/ $12 \mathrm{wt}$ \% CFM) it also consists of three main degradation steps, but these materials present also an additional very small degradation step $(\sim 1.5 \%$ mass loss $)$ between $40-170{ }^{\circ} \mathrm{C}$ which can be ascribe with the evaporation of absorbed water by the hydrophilic groups of the chicken feathers. The main step of thermal decomposition for composites with chicken feathers occurs between $200{ }^{\circ} \mathrm{C}$ and $450{ }^{\circ} \mathrm{C}$ where the material loss around $60 \%$ from its mass. From $450{ }^{\circ} \mathrm{C}$ to $650{ }^{\circ} \mathrm{C}$ take place the oxidative thermal degradation of $\sim 25-30 \%$ of the CF composite weight mass. For the material with CFP or CFM the third step of thermal degradation arises faster than that of the neat matrix or of the composite with lignin.

Table 2. Thermal characterization of the resins and bio-composites

\begin{tabular}{ccccc}
\hline & \multicolumn{3}{c}{$\mathbf{T}_{5 \%}\left[{ }^{\circ} \mathbf{C}\right]$} \\
\cline { 2 - 5 } & Neat & Resin-10CFP & Resin-12CFM & Resin-10L \\
\hline CFP & $239 \pm 2$ & & & \\
CFM & $236 \pm 1$ & & & \\
HP40B5 & $202 \pm 2$ & $240 \pm 2$ & $241 \pm 1$ & $240 \pm 1$ \\
HP20G20B5 & $212 \pm 1$ & $235 \pm 3$ & $240 \pm 2$ & $245 \pm 1$ \\
HG40B5 & $232 \pm 1$ & $232 \pm 2$ & $235 \pm 2$ & $250 \pm 1$ \\
\hline
\end{tabular}

\subsubsection{Dynamic mechanical thermal analysis (DMA)}

Dynamic mechanical analyses (DMA) were used to analyze the mechanical properties of the humins-based resins and their bio-composites. A sinusoidal stress was applied to determine the storage and loss moduli but also the damping factor of these materials. The effect of temperature and of the bio-fillers presence in the thermoset matrices on the storage modulus (E') and loss modulus (E') of the samples at a frequency of $1.0 \mathrm{~Hz}$ are given in Figure 3 and Table 2SI.

According with the obtained data the filler influences both moduli of the materials. The storage modulus value in the glassy region (at around $-70^{\circ} \mathrm{C}$ ) drops considerably in presence of the bio-filler in the polymer matrix. The order in which the E' decreases for all three resins and composites materials is as follows: Resins $>$ Composites with 10L > Composites with 10CFP > Composites with 12CFM. Nevertheless, it is important to emphasize the composite behavior at higher temperatures, in the rubbery region. Is already know from literature (Gupta, Drzal, Lee, \& Rich, 1985; Ullah \& Wu, 2013) that in the rubbery plateau, the storage modulus depends highly on the density of the material's crosslinks such that the bigger the crosslinking density of the materials, the smaller the drop of the storage modulus value. In the case of composites with lignin, the loss modulus values in the glassy region are similar to that of neat resins, meanwhile a significant increase occurs in the case of composites with feathers, the highest being for the materials with CFM. We can observe that for HP40B5 system, the addition of 12 wt.\% CFM increases with four times the E" modulus value in glassy plateau (from 1 to $5 \mathrm{MPa}$ ), while for the 
HG40B5 the increase is up to eight times higher compared to the neat matrix (from 6 to $42 \mathrm{MPa}$ ). Also, the DMA tests can generate important information about a mechanical parameter important in the design and production of materials, namely their brittleness (B). Following the studies developed by W. Brostow et al. (Brostow, Hagg Lobland, \& Narkis, 2011, 2006; Brostow \& Hagg Lobland, 2010) it has been shown that the brittleness (B) of the materials is inversely proportional to the storage modulus (E') at a frequency of $1.0 \mathrm{~Hz}$.
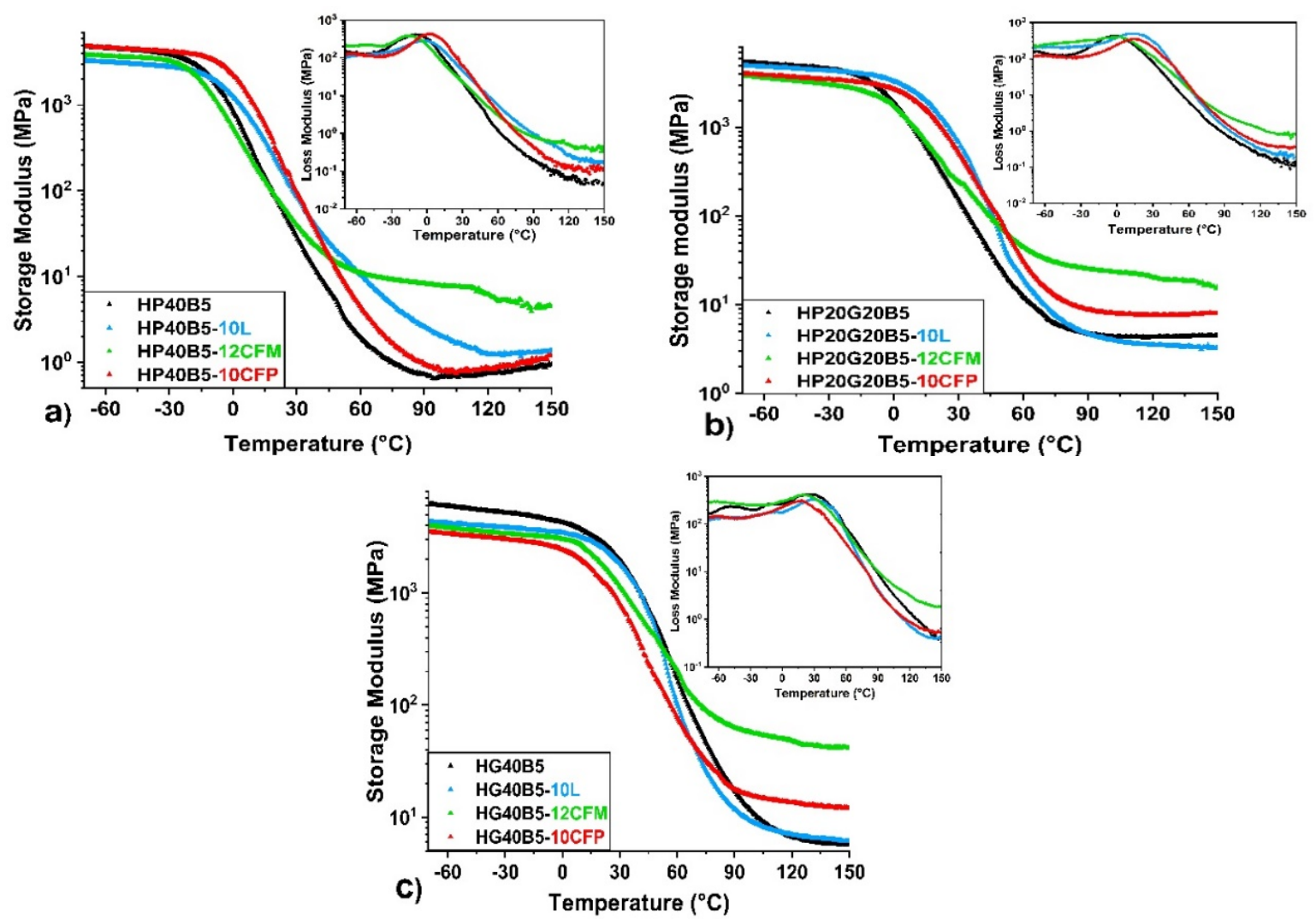

Figure 3. Comparison of the evolution of storage and loss moduli vs. temperature for the three huminsbased resins (black line) and their bio-composites with: Resin-10L (blue line), Resin-10CFP (red line), Resin-12CFM (green line)

The crosslinking density of the materials was also calculated (Table 2ESI) using the Flory's theory (Flory, 1953) and compared with the values obtained for the neat resins. In the Figure 4 is represented the evolution with temperature of the damping factor of the resin's materials and their bio-composites. The damping factor was determined by the ratio between the loss and the storage moduli (E'/E'), showing the width of the glass transition regions of the materials (Kalogeras \& Hagg Lobland, 2012). For the composites with 12CFM it can be observed a decrease of the intensity of $\tan \delta$ peak and also a shift of its maximum to lower temperatures compared with the neat resins which means that the reinforcement improves the elasticity of the materials. According to the maximum values of $\tan \delta$ peak, CFP act differently on the polymer resin depending on its nature. From Figure 4a we can observe that the damping factor curves for the HP40B5 elastic matrix and for the composite with CFP are similar, showing the same height of the peak but the maximum of $\tan \delta$ of the resin is higher with $5{ }^{\circ} \mathrm{C}$ compared with the composite. This similarity between the two curves may show that the chicken feathers powder is fully compatible and integrated in the elastic matrix composition, the cross-linking density being almost the same $\left(0.7-0.8 \mathrm{mmol} . \mathrm{cm}^{-}\right.$ $\left.{ }^{3}\right)$. In the case of the rigid resin, HG40B5, the maximum value of $\tan \delta$ is shifted to a lower temperature which means that the CFP filler acts like a plasticizer for the matrix. 

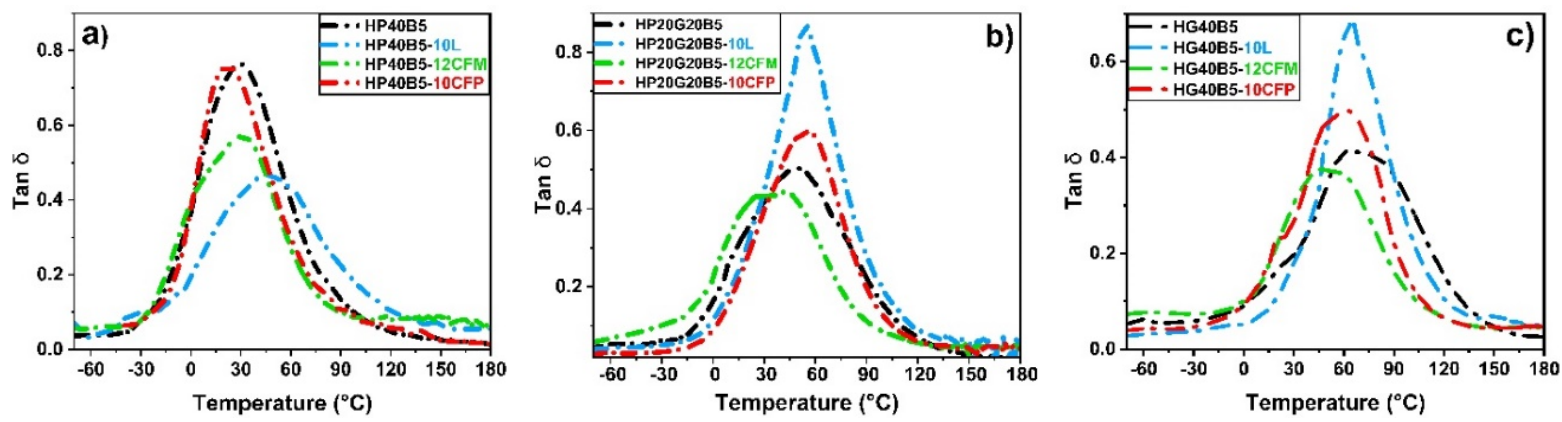

Figure 4. Evolution with temperature of $\tan \delta$ of the three resins and their bio-composites

The thermal properties of the materials measured by DMA according with ASTM D7028-07 (ASTM-D7028, 2008) were in accordance with the results obtained by DSC and are presented in Table 3ESI. The density of materials is an important concept in terms of their use, representing the degree of compactness of materials; mathematically it is defined as mass divided by volume $(\rho=\mathrm{m} / \mathrm{v})$. So, two materials with the same weight can have different density, the lower dense material occupying more volume than higher dense material. Therefore, the resins and composites densities (Table 3) were determined and compared in order to analyze the influence of the bio-filler.

Table 3 . Density of the three resins and their related composites

\begin{tabular}{lccc}
\hline \multirow{2}{*}{ Sample } & \multicolumn{3}{c}{ Density $\left[\mathbf{g} / \mathbf{c m}^{3}\right]$} \\
\cline { 2 - 4 } & HP40B5 & HP20G20B5 & HG40B5 \\
\hline Neat Resin & 1.23 & 1.22 & 1.25 \\
Resin- 10L & 1.25 & 1.28 & 1.29 \\
Resin- 12CFM & 1.11 & 1.10 & 1.11 \\
Resin- 10CFP & 1.10 & 1.11 & 1.01 \\
\hline
\end{tabular}

According with the literature, it was already reported (Reddy \& Yang, 2007; Tesfaye et al., 2017) that the properties of chicken feathers make them preferable for several applications due to their low-density $\left(0.8 \mathrm{~g} / \mathrm{cm}^{3}\right)$ compared with that of the wool $\left(1.3 \mathrm{~g} / \mathrm{cm}^{3}\right)$ or cellulose fibers $\left(1.5 \mathrm{~g} / \mathrm{cm}^{3}\right)$. The density values determined for the HP40B5, HP20G20B5 and HG40B5 resins are $1.23,1.22$ and $1.25 \mathrm{~g} / \mathrm{cm}^{3}$, respectively. As can be seen in Table 3, the addition of lignin to the polymeric matrix increases the density of the composites with approximately $0.02-$ $0.06 \mathrm{~g} / \mathrm{cm}^{3}$ compared to the neat resins. For the composites developed with CFP or CFM, the low density of the chicken feathers decreased the density of the composites, thus obtaining values between 1.01 and $1.11 \mathrm{~g} / \mathrm{cm}^{3}$.

\subsubsection{Tensile testing}

The mechanical properties of the materials are essential parameters determining the industrial area of their use. The Young's modulus, tensile strength and the elongation at break of each type of humins-based resin were compared with the values obtained for the composites made with lignin, chicken feathers powder or mat and are presented in Figure 5 and Table 4. According with the reported results (Cheng et al., 2009; Flores-Hernández et al., 2014; Zhan \& Wool, 2016), the reinforcement of polymeric matrix with chicken feathers decreases more or less the elongation at break or the tensile strength of the composites.

Fully biodegradable bio-composite were developed by Aranberri et al. (2017) using three biodegradable matrices (polylactic acid (PLA), polybutyrate adipate terephthalate (PBAT) and a PLA/thermoplastic copolyester blend) and a high loadings of chicken feathers (50-60 wt.\%) as reinforcement. The authors investigated and compared the mechanical properties of the three matrices with those obtained for bio-composites with CF. It was observed that the addition of feathers affects the mechanical properties of the composites in comparison with the neat matrix (e.g. elongation at break from 570\% for PBAT resin decreased to $2.5 \%$ for PBAT 50\% /CF 50\% bio-composite), but on the other way improved the lightweight and thermal-insulating of the materials converting them as a good alternative to wood-plastic composites. In another study (Aranberri et al., 2018), were developed composites with poly(urea-urethane)/chicken feather fibers (different ratios) with similar mechanical properties to those presented in this study. The Young's modulus of the composites developed by Aranberri et al. (2018) is range 1.2-410 MPa 
in function of the polymer/CF ratio, while for the bio-materials developed in this study is from $1 \mathrm{MPa}$ to $800 \mathrm{MPa}$ depending on the resin or filler nature.
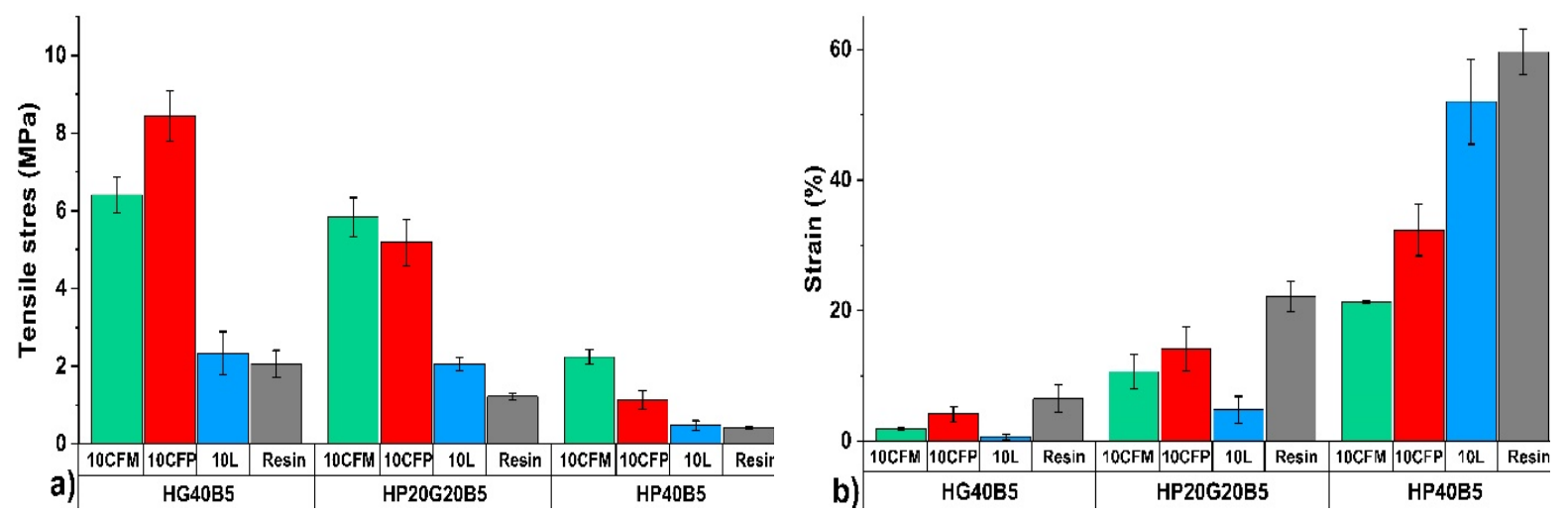

Figure 5. Comparison between tensile properties of the neat resins and composites: a) tensile stress; b) strain of the materials

Table 4. Tensile properties of the three neat resins and composites materials

\begin{tabular}{|c|c|c|c|c|}
\hline & & $\begin{array}{c}\text { Young's Modulus } \\
\text { [MPa] }\end{array}$ & $\begin{array}{c}\text { Maximum Stress } \\
{[\mathrm{MPa}]}\end{array}$ & $\begin{array}{c}\text { Maximum Strain } \\
{[\%]}\end{array}$ \\
\hline \multirow{4}{*}{$\begin{array}{l}\text { ồ } \\
\hat{\theta} \\
\hat{\Xi} \\
\hat{\Xi}\end{array}$} & Neat Resin & $1.01 \pm 0.08$ & $0.41 \pm 0.04$ & $59.66 \pm 3.53$ \\
\hline & Resin-10L & $1.60 \pm 0.40$ & $0.47 \pm 0.13$ & $52.02 \pm 18.25$ \\
\hline & Resin-10CFP & $5.05 \pm 1.18$ & $1.13 \pm 0.23$ & $32.33 \pm 3.94$ \\
\hline & Resin- 12CFM & $22.36 \pm 4.96$ & $2.24 \pm 0.18$ & $21.37 \pm 1.49$ \\
\hline \multirow{4}{*}{ 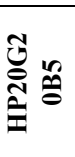 } & Neat Resin & $8.29 \pm 0.61$ & $1.22 \pm 0.09$ & $22.16 \pm 2.3$ \\
\hline & Resin-10L & $105.85 \pm 22.65$ & $2.05 \pm 0.17$ & $4.82 \pm 2.04$ \\
\hline & Resin-10CFP & $112.81 \pm 27.84$ & $5.19 \pm 2.22$ & $14.12 \pm 6.41$ \\
\hline & Resin- 12CFM & $134.02 \pm 39.10$ & $5.84 \pm 0.90$ & $10.66 \pm 2.58$ \\
\hline \multirow{4}{*}{ 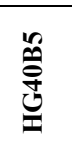 } & Neat Resin & $106.1 \pm 39.82$ & $2.06 \pm 0.55$ & $6.49 \pm 2.11$ \\
\hline & Resin-10L & $667.18 \pm 260.91$ & $2.34 \pm 1.16$ & $0.71 \pm 0.42$ \\
\hline & Resin-10CFP & $346.30 \pm 57.13$ & $8.44 \pm 1.25$ & $4.17 \pm 1.14$ \\
\hline & Resin- 12CFM & $442.76 \pm 17.92$ & $6.41 \pm 0.70$ & $1.90 \pm 0.26$ \\
\hline
\end{tabular}

From figure 5 we can highlight that the tensile stress values of all bio-composites were considerably improved compared to that of resins, but this improvement depends on the nature of the filler but also of the resin formulation. Considering the nature of the bio-filler, it can be observed that the tensile strength of the composites increases in the following bio-filler order: $\mathrm{L}<\mathrm{CFP}<\mathrm{CFM}$, apart from the HG40B5 resin where the bio-composites with chicken feathers powder show the highest increase in tensile strength. In the case of HP40B5 ductile matrix, the tensile strength of the composite with lignin was improved with $13 \%$ compared with the neat resin. For the same matrix, the composite with 10CFP has a tensile modulus with $64 \%$ higher while the composite with 12CFM has a tensile value increased with $82 \%$ compared to that of the matrix. For the HG40B5 rigid matrix, the addition of lignin improved the tensile modulus with $12 \%$, while the addition of 10 CFP enhanced the tensile strength with $76 \%$ and the addition of $12 \mathrm{CFM}$ with $68 \%$ compared with the neat resin. Such results could be the effect from a better stress transfer between the matrix and the bio-fillers. The elongation at break of the bio-composites decreases (depending on the nature of the filler) which shows that the fillers increased the materials' rigidity. The stiffness of the obtained materials, defined by the relationship between stress and strain in the linear elasticity regime of a uniaxial deformation, are presented in Table 4 as Young's modulus values. As in the case of strain results, the values of the Young's modulus were considerably improved for all three types of bio-composites, but the highest values were obtained for the composites with $12 \mathrm{wt} . \%$ CFM. For example, in the case of the HP40B5 elastic resin the Young's modulus value was improved from 1 to $22 \mathrm{MPa}$, while for the HG40B5 (rigid resin) the increase was from 106 to $443 \mathrm{MPa}$. Consulting the MatWeb online database (http://www.matweb.com/index.aspx), the mechanical properties of the materials developed in this study have been compared with the commercial ones 
showing that have comparable performances for e.g. with Silicone Rubber/Fiberglass, Epoxy/Carbon Fiber Composites.

\subsubsection{Water absorption}

The water absorptions of the neat resins and their bio-composites with $10 \mathrm{wt} . \%$ CFP, $12 \mathrm{wt} . \%$ CFM and $10 \mathrm{wt} . \%$ $\mathrm{L}$ are represented in Figure 4ESI. The samples were immersed in distilled water at $25^{\circ} \mathrm{C}$ and have been maintained until they have reached a steady state. Both resins and composites were kept in the water for 11 days, their weight being measured daily. It can be observed that the water absorption (average value) of the neat resins increases with the increasing of the elasticity of the materials: HG40B5 (10.1\%WA) < HP20G20B5 (11.3\%WA) < HP40B5 $(13.4 \% \mathrm{WA})$. For the composites with $10 \mathrm{wt} . \% \mathrm{~L}$ was observed an increasing of water absorption with around 2$4 \%$ compared with the neat resins. In the case of bio-composites with $10 \mathrm{wt} . \% \mathrm{CFP}$ and with $12 \mathrm{wt} \% \mathrm{CFM}$ the water gain is similar. By comparing the percentage of water absorbed by neat resins with that absorbed by the biocomposites with CFP and CFM ( 24-26\%WA), one can observe that the water absorption increases two times for the last one. According to the literature (Belarmino et al., 2012; Ana Laura Martínez-Hernández \& Carlos VelascoSantos, 2012; Reddy \& Yang, 2007; Staron et al., 2011), the high water gain of the composites with feathers compared with that of resins is mainly attributed to the high hygroscopic character of keratin from feathers. The results obtained are in agreement with the results already published (Aranberri et al., 2018, 2017; Colom, Rahalli, Cañavate, \& Carrillo, 2015; Hong \& Wool, 2005), in which the addition of CFP's increases significantly the water absorption in a composite irrespective of the nature of the polymeric matrix.

\subsubsection{Scanning electron microscopy (SEM)}

To study the compatibility and the adhesion between the bio-fillers and the resins, the obtained composites were analyzed by SEM. In the Figure 6 are revealed the SEM results at different resolutions as $100 \mu \mathrm{m}, 50 \mu \mathrm{m}$ and 10 $\mu \mathrm{m}$ for the composites developed with $10 \mathrm{wt} \% \mathrm{CFP}$.

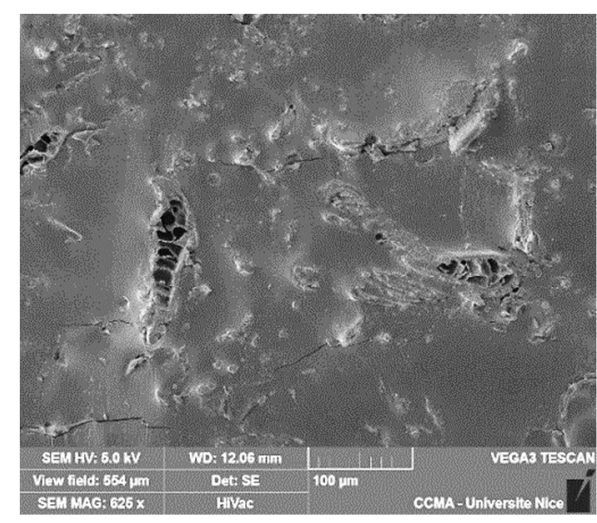

a) $100 \mathrm{\mu m}$

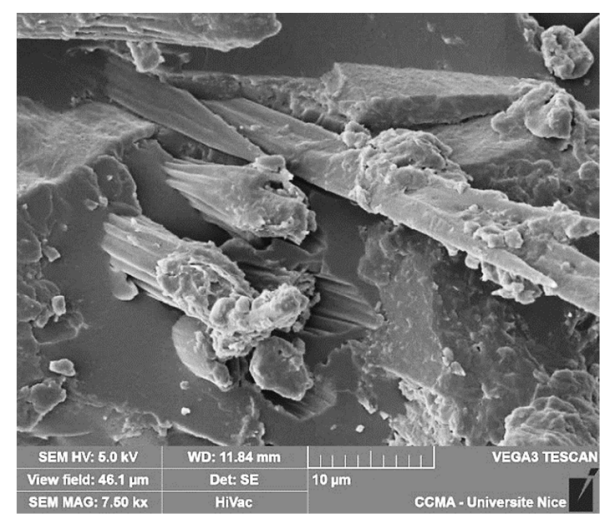

c) $10 \mathrm{\mu m}$

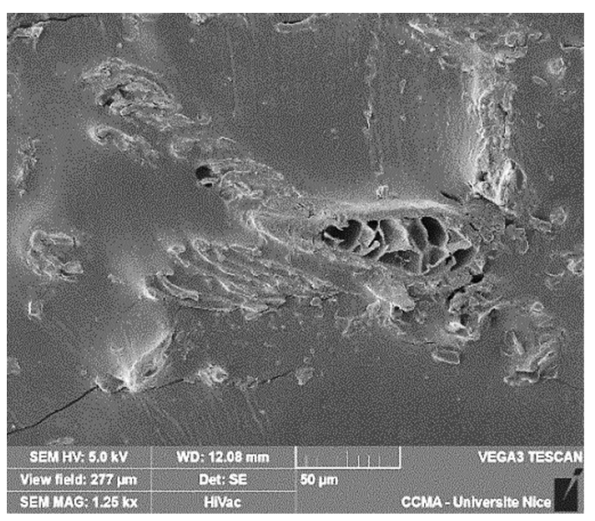

b) 50 rm

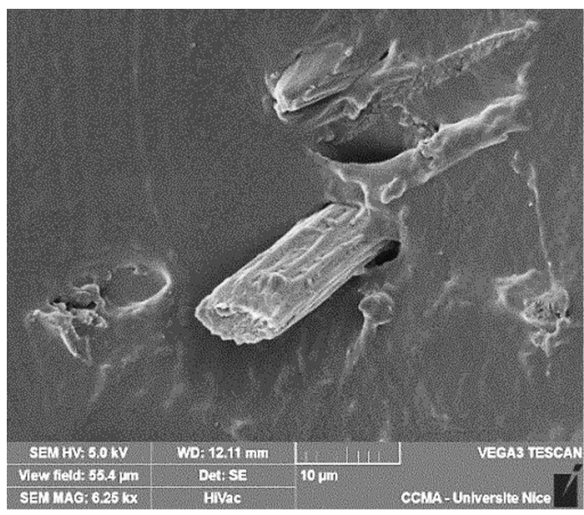

d) $10 \mathrm{\mu m}$

Figure 6. SEM images for HG40B5 composites with $10 \mathrm{wt} . \%$ CFP 
The surface's fracture of the composites was analyzed to evaluate the adhesion of the matrix on the chicken feathers but also the appearance of the resin. It can be observed that the compatibility between chicken feathers and humins-based matrix is very good, we cannot observe spaces or voids between the humins polymeric matrix and the $\mathrm{CF}$ fibers. It can also be seen that the humins matrix remains attached to the fibers after the sample fracture. In the same time, the surface of the humins-matrix shows a smooth and homogeneous appearance.

\section{Conclusions}

In this study, bio-composites were developed using three types of humins-based resins and chicken feathers powder, chicken feathers non-woven mat or lignin. The influence of nature and amount of filler on the crosslinking reactions were studied by DSC analyses and rheology and compared with the corresponding neat resins. Therefore, the thermomechanical properties of the obtained bio-composites were investigated. The thermal stability of the composites was maintained or improved with around $20-30{ }^{\circ} \mathrm{C}$ compared with the resins. The DMA analyses show that the filler influences the storage modulus of the bio-composites. In the glassy region $\left(-70{ }^{\circ} \mathrm{C}\right)$ this modulus significantly decreases for all bio-composite materials. In the rubbery plateau, the E' values of the composites with lignin are similar with that of neat resins, while that of the bio-composites with chicken feathers increased considerably. It has to be noticed that not only the nature of the filler influences the mechanical properties of the materials, but also its form, the composites with chicken feathers powder having a lower value of the storage modulus compared to the materials developed with chicken feathers mats.

The mechanical tensile properties of the bio-composites were considerably improved compared with that of the resins. In the case of the ductile matrix the tensile modulus increased by $82 \%$, in presence of $12 \mathrm{CFM}$, while for the rigid matrix the increase was till $76 \%$ with 10CFP. Then, for the ductile matrix the Young's modulus value was improved from 1 to $22 \mathrm{MPa}$, while for the rigid matrix the increase was from 106 to 443 or $667 \mathrm{MPa}$, in the case of composites with chicken feathers non-woven mat or lignin.

The addition of the bio-fillers in the humins matrix affect the water absorption behavior. The bio-composites with lignin show an increase in water stability of about $2-4 \%$ compared to the neat resins, while that with feathers increased twice times. The compatibility between humins-based resins and the chicken feathers is excellent, a very good adhesion between the polymer matrix and the reinforcing material was observed by SEM.

In conclusion, humins-based resins were successfully reinforced with natural and valuable bio-fillers obtained by industrial wastes, thus obtaining eco-friendly composite materials with properties that could recommend them for various industrial applications.

\section{Conflicts of interest}

The authors declare that there is no conflict of interests regarding the publication of this paper.

\section{Acknowledgements}

Funding for this work was received from the European Union's Horizon 2020 Research and Innovation program under Grant Agreement 723268 on a project KaRMA2020.

Also, the authors acknowledge M. Francois Orange for his help and assistance with SEM observations performed at CCMA Common Centre of Applied Electronic Microscopy of University Côte d'Azur. CCMA electron microscopy equipment has been funded by the Region Sud - Provence-Alpes-Côte d'Azur, the Conseil General des Alpes Maritimes, and the GIS-IBiSA.

\section{References}

Abreu, H. D. S., Nascimento, A. M. Do, \& Maria, M. A. (1999). Lignin structure and wood properties. Wood and Fiber Science, 31(4), 426-433.

Amieva, E. J.-C., Velasco-Santos, C., Martínez-Hernández, A., Rivera-Armenta, J., Mendoza-Martínez, A., \& Castaño, V. (2015). Composites from chicken feathers quill and recycled polypropylene. Journal of Composite Materials, 49(3), 275-283. https://doi.org/10.1177/0021998313518359

Aranberri, I., Montes, S., Azcune, I., Rekondo, A., \& Grande, H.-J. (2018). Flexible Biocomposites with Enhanced Interfacial Compatibility Based on Keratin Fibers and Sulfur-Containing Poly(urea-urethane)s. Polymers, 10(10), 1056. https://doi.org/10.3390/polym10101056

Aranberri, I., Montes, S., Azcune, I., Rekondo, A., \& Grande, H. J. (2017). Fully biodegradable biocomposites with high chicken feather content. Polymers, 9(11). https://doi.org/10.3390/polym9110593

Astbury, W. T., \& Street, A. (1931). X-ray studies of the structure of hair, wool, and related fibres.- I. General. Philosophical Transactions of the Royal Society A, 230, 681-693. 
ASTM-D570. (1998). Water Absorption of Plastics. https://doi.org/10.1520/D0570-98

ASTM-D7028. (2008). Standard Test Method for Glass Transition Temperature (DMA Tg) of Polymer Matrix Composites by Dynamic Mechanical Analysis (DMA). https://doi.org/10.1520/D7028-07E01.2

Barone, J. R., \& Schmidt, W. F. (2005). Polyethylene reinforced with keratin fibers obtained from chicken feathers. Composites Science and Technology, 65(2), 173-181. https://doi.org/10.1016/j.compscitech.2004.06.011

Belarmino, D. D., Ladchumananandasivam, R., Belarmino, L. D., Pimentel, J. R. de M., da Rocha, B. G., Galvão, A. O., \& de Andrade, S. M. B. (2012). Physical and Morphological Structure of Chicken Feathers (Keratin Biofiber) in Natural, Chemically and Thermally Modified Forms. Materials Sciences and Applications, 03(12), 887-893. https://doi.org/10.4236/msa.2012.312129

Bessa, J., Souza, J., Lopes, J. B., Sampaio, J., Mota, C., Cunha, F., \& Fangueiro, R. (2017). Characterization of thermal and acoustic insulation of chicken feather reinforced composites. Procedia Engineering, 200, 472479. https://doi.org/10.1016/j.proeng.2017.07.066

Brostow, W., Hagg Lobland, H. E., \& Narkis, M. (2011). The concept of materials brittleness and its applications. Polymer Bulletin, 67(8), 1697-1707. https://doi.org/10.1007/s00289-011-0573-1

Brostow, W., \& Hagg Lobland, H. E. (2010). Brittleness of materials: Implications for composites and a relation to impact strength. Journal of Materials Science, 45(1), 242-250. https://doi.org/10.1007/s10853-009-39265

Brostow, W., \& Hagg Lobland, H. E. (2017). Materials: Introduction and Applications. John Wiley and Sons.

Brostow, W., Hagg Lobland, H. E., \& Narkis, M. (2006). Sliding wear, viscoelasticity, and brittleness of polymers. Journal of Materials Research, 21(9), 2422-2428. https://doi.org/10.1557/jmr.2006.0300

Cheng, S., Lau, K., Liu, T., Zhao, Y., Lam, P., \& Yin, Y. (2009). Mechanical and thermal properties of chicken feather fiber/PLA green composites. Composites Part B: Engineering, 40(7), 650-654. https://doi.org/10.1016/j.compositesb.2009.04.011

Cheung, H.-Y., Ho, M.-P., Lau, K.-T., Cardona, F., \& Hui, D. (2009). Natural fibre-reinforced composites for bioengineering and environmental engineering applications. Composites Part B: Engineering, 40(7), 655663. https://doi.org/10.1016/j.compositesb.2009.04.014

Chirayil, C. J., Mathew, L., Hassan, P. A., Mozetic, M., \& Thomas, S. (2014). Rheological behaviour of nanocellulose reinforced unsaturated polyester nanocomposites. International Journal of Biological Macromolecules, 69, 274-281. https://doi.org/10.1016/j.ijbiomac.2014.05.055

Colom, X., Rahalli, A., Cañavate, J., \& Carrillo, F. (2015). Properties and optimal manufacturing conditions ao chicken feathers thermoplastic biocomposites. Journal of Composite Materials, 49(3). https://doi.org/10.1177/0021998313518569

Delidovich, I., Hausoul, P. J. C., Deng, L., Pfützenreuter, R., Rose, M., \& Palkovits, R. (2016). Alternative Monomers Based on Lignocellulose and Their Use for Polymer Production. Chemical Reviews, 116(3), 1540-1599. https://doi.org/10.1021/acs.chemrev.5b00354

Dinu, R., \& Mija, A. (2019). Cross-linked polyfuran networks with elastomeric behaviour based on humins biorefinery by-products. Green Chemistry, 21, 6277-6289. https://doi.org/10.1039/c9gc01813a

Diop, A., Mijiyawa, F., Koffi, D., Kokta, B. V., \& Montplaisir, D. (2015). Study of lignin dispersion in low-density polyethylene. Journal of Thermoplastic Composite Materials, 28(12), 1662-1674. https://doi.org/10.1177/0892705714556829

Donato, R. K., \& Mija, A. (2019). Keratin Associations with Synthetic, Biosynthetic and Natural Polymers: An Extensive Review. Polymers, 12(1), 32. https://doi.org/10.3390/polym12010032

FAO. (2019). Food Outlook - Biannual Report on Global Food Markets.

Feghali, E., Torr, K. M., Pas, D. J. van de, Ortiz, P., Vanbroekhoven, K., Eevers, W., \& Vendamme, R. (2018). Thermosetting polymers from lignin model compounds and depolymerized lignins. Topics in Current Chemistry, 376(32). https://doi.org/10.1007/s41061-018-0211-6

Flores-Hernández, C., Colín-Cruz, A., Velasco-Santos, C., Castaño, V., Rivera-Armenta, J., AlmendarezCamarillo, A., ... Martínez-Hernández, A. (2014). All Green Composites from Fully Renewable Biopolymers: Chitosan-Starch Reinforced with Keratin from Feathers. Polymers, 6(3), 686-705. https://doi.org/10.3390/polym6030686 
Flory, P. J. (1953). Principles of Polymer Chemistry. Ithaca, New York: Cornell University Press.

Fraser, R.D. Bruce, \& Parry, D. A. D. (2011). The structural basis of the filament-matrix texture in the avian/reptilian group of hard $\beta$-keratins. Journal of Structural Biology, 173(2), 391-405. https://doi.org/10.1016/j.jsb.2010.09.020

Fraser, R.D.B., Macrae, T. P., Parry, D. A. D., \& Suzuki, E. (1969). The structure of $\beta$-Keratin. Polymer, 10, 810826. https://doi.org/10.1016/0032-3861(69)90110-4

Fraser, R D B, \& MacRae, T. P. (1973). The structure of $\alpha$-keratin. Polymer, 14(February), 61-67.

G, B., \& VK, S. (2016). Review on Chicken Feather Fiber (CFF) a Livestock Waste in Composite Material Development. International Journal of Waste Resources, 6(4), 4-7. https://doi.org/10.4172/22525211.1000254

Garrido, T., Peñalba, M., de la Caba, K., \& Guerrero, P. (2019). A more efficient process to develop protein films derived from agro-industrial by-products. Food Hydrocolloids, 86, 11-17. https://doi.org/10.1016/j.foodhyd.2017.11.023

Gorobets, L., \& Kovalchuk, O. (2017). Birds in the medieval culture and economy of the East Slavs in the 1013th centuries AD. Environmental Archaeology, 22(2), 147-165. https://doi.org/10.1080/14614103.2016.1141088

Gupta, V. B., Drzal, L. T., Lee, C. Y. -., \& Rich, M. J. (1985). The temperature-dependence of some mechanical properties of a cured epoxy resin system. Polymer Engineering \& Science, 25(13), 812-823. https://doi.org/10.1002/pen.760251305

Gurav, R. G., \& Jadhav, J. P. (2013). A novel source of biofertilizer from feather biomass for banana cultivation. Environ Sci Pollut Res, 4532-4539. https://doi.org/10.1007/s11356-012-1405-z

Hadas, A., \& Kautsky, L. (1994). Feather meal, a semi-slow-release nitrogen fertilizer for organic farming. Fertilizer Research, 38(2), 165-170. https://doi.org/10.1007/BF00748776

Halley, P. J., \& Mackay, M. E. (1996). Chemorheology of thermosets?an overview. Polymer Engineering \& Science, 36(5), 593-609. https://doi.org/10.1002/pen.10447

Hong, C. K., \& Wool, R. P. (2005). Development of a bio-based composite material from soybean oil and keratin fibers. Journal of Applied Polymer Science, 95(6), 1524-1538. https://doi.org/10.1002/app.21044

$\mathrm{Hu}, \mathrm{X}$., Lievens, C., Larcher, A., \& Li, C. Z. (2011). Reaction pathways of glucose during esterification: Effects of reaction parameters on the formation of humin type polymers. Bioresource Technology, 102(21), 1010410113. https://doi.org/10.1016/j.biortech.2011.08.040

Hu, X., Lievens, C., \& Li, C. Z. (2012). Acid-catalyzed conversion of xylose in methanol-rich medium as part of biorefinery. ChemSusChem, 5(8), 1427-1434. https://doi.org/10.1002/cssc.201100745

Huda, S., \& Yang, Y. (2008). Composites from ground chicken quill and polypropylene. Composites Science and Technology, 68(3-4), 790-798. https://doi.org/10.1016/j.compscitech.2007.08.015

Kalogeras, I. M., \& Hagg Lobland, H. E. (2012). The nature of the glassy state: Structure and glass transitions. Journal of Materials Education, 34(3-4), 69-94.

Kang, S., Fu, J., Deng, Z., Jiang, S., Zhong, G., Xu, Y., Zhou, J. (2018). Valorization of biomass hydrolysis waste: Activated carbon from humins as exceptional sorbent for wastewater treatment. Sustainability (Switzerland), 10(6), 16-19. https://doi.org/10.3390/su10061795

Khosa, M. A., \& Ullah, A. (2013). A Sustainable Role of Keratin Biopolymer in Green Chemistry: A Review. Journal of Food Processing \& Beverages, 1(1), 1-8.

Lewin, M. (2007). Handbook of Fiber Chemistry (3rd ed.). New York: CRC Press Taylor \& Francis Group.

Martínez-Hernández, A.L., Velasco-Santos, C., De-Icaza, M., \& Castaño, V. M. (2007). Dynamical-mechanical and thermal analysis of polymeric composites reinforced with keratin biofibers from chicken feathers. Composites Part B: Engineering, 38(3), 405-410. https://doi.org/10.1016/j.compositesb.2006.06.013

Martínez-Hernández, Ana Laura, \& Velasco-Santos, C. (2012). Keratine fibers from chicken feathers: Structure and advances in polymer composites. In R. Dullaart (Ed.), Keratin: Structure, Properties and Applications (pp. 149-211).

McLelland, J. (1990). A Colour Atlas of Avian Anatomy. London: Wolfe Publishing Ltd. 
Mija, A., Jong, E. De, Waal, J. C. Van der, \& Klink, G. P. M. Van. (2017). Patent No. WO 2017/074183 A1.

Mishra, P. K., \& Ekielski, A. (2019). The Self-Assembly of Lignin and Its Application in Nanoparticle Synthesis: A Short Review. Nanomaterials, 9(2), 243. https://doi.org/10.3390/nano9020243

Pauling, L., Corey, R. B., \& Branson, H. R. (1951). The structure of proteins: Two hydrogen-bonded helical configurations of the polypeptide chain. Proceedings of the National Academy of Sciences of the United States of America, 37(4), 205-211.

Pin, J. M., Guigo, N., Mija, A., Vincent, L., Sbirrazzuoli, N., Van Der Waal, J. C., \& De Jong, E. (2014). Valorization of biorefinery side-stream products: Combination of humins with polyfurfuryl alcohol for composite elaboration. ACS Sustainable Chemistry and Engineering, 2(9), 2182-2190. https://doi.org/10.1021/sc5003769

Pin, J. M., Guigo, N., Vincent, L., Sbirrazzuoli, N., \& Mija, A. (2015). Copolymerization as a Strategy to Combine Epoxidized Linseed Oil and Furfuryl Alcohol: The Design of a Fully Bio-Based Thermoset. ChemSusChem, 8(24), 4149-4161. https://doi.org/10.1002/cssc.201501259

Ponnusamy, V. K., Nguyen, D. D., Dharmaraja, J., Shobana, S., Banu, J. R., Saratale, R. G., ... Kumar, G. (2019). A review on lignin structure, pretreatments, fermentation reactions and biorefinery potential. Bioresource Technology, 271, 462-472. https://doi.org/10.1016/j.biortech.2018.09.070

Poole, A. J., Church, J. S., \& Huson, M. G. (2009). Environmentally Sustainable Fibers from Regenerated Protein. Biomacromolecules, 10(1), 1-8. https://doi.org/10.1021/bm8010648

Pourjavaheri, F., Mohades, F., Jones, O., Sherkat, F., Kong, I., Gupta, A., \& Shanks, R. A. (2017). Avian keratin fibre-based bio-composites. World Journal of Engineering, 14(3), 183-187. https://doi.org/10.1108/WJE08-2016-0061

Reddy, N. (2015). Non-food industrial applications of poultry feathers. Waste Management, 45, 91-107. https://doi.org/10.1016/j.wasman.2015.05.023

Reddy, N., Chen, L., \& Yang, Y. (2013). Biothermoplastics from hydrolyzed and citric acid Crosslinked chicken feathers. Materials Science and Engineering: C, 33(3), 1203-1208. https://doi.org/10.1016/j.msec.2012.12.011

Reddy, N., \& Yang, Y. (2007). Structure and Properties of Chicken Feather Barbs as Natural Protein Fibers. Journal of Polymers and the Environment, 15(2), 81-87. https://doi.org/10.1007/s10924-007-0054-7

Rivera, E. M., Araiza, M., Brostow, W., Castaño, V. M., Díaz-Estrada, J.R., Hernández, R., \& Rodríguez, J. R. (1999). Synthesis of hydroxyapatite from eggshells. Materials Letters, 41(3), 128-134. https://doi.org/10.1016/S0167-577X(99)00118-4

Sah, N., Goel, A., \& Omre, P. K. (2015). Characterization of Chicken Feather Fibre as Novel Protein Fiber for Commercial Applications. International Journal of Tropical Agriculture, 33(4), 3373-3378.

Saravanan, K., \& Dhurai, B. (2012). Exploration on Amino Acid Content and Morphological Structure in Chicken Feather Fiber. Journal of Textile and Apparel, Technology and Management, 7(3), 1-6.

Seawright, R. A., Marcicano, J. P. P., \& Navarrete, F. C. (2013). Study of Physical Properties of Chicken Feathers for Commercial Use. 3(2), 1-7.

Sharma, S., \& Gupta, A. (2016). Sustainable Management of Keratin Waste Biomass: Applications and Future Perspectives. Brazilian Archives of Biology and Technology, 59(December), 1-14. https://doi.org/10.1590/1678-4324-2016150684

Shi, Z., Reddy, N., Hou, X., \& Yang, Y. (2014). Tensile Properties of Thermoplastic Feather Films Grafted with Different Methacrylates. ACS Sustainable Chem. Eng., 2, 1849-1856.

Song, N.-B., Lee, J.-H., Al Mijan, M., \& Song, K. Bin. (2014). Development of a chicken feather protein film containing clove oil and its application in smoked salmon packaging. LWT - Food Science and Technology, 57(2), 453-460. https://doi.org/10.1016/j.lwt.2014.02.009

Spiridon, I. (2018). Biological and Pharmaceutical Applications of Lignin and Its Derivatives: a Mini-Review. Cellulose Chem. Technol, 52(8), 543-550. Retrieved from http://www.cellulosechemtechnol.ro/pdf/CCT78(2018)/p.543-550.pdf

Staron, P., Banach, M., \& Kowalski, Z. (2011). Keratin - origins, properties, application. Chemik, 65(10), 10191026. 
Tesfaye, T., Sithole, B., Ramjugernath, D., \& Chunilall, V. (2017). Valorisation of chicken feathers: Characterisation of physical properties and morphological structure. Journal of Cleaner Production, 149, 349-365. https://doi.org/10.1016/j.jclepro.2017.02.112

Thakur, V. K., Thakur, M. K., Raghavan, P., \& Kessler, M. R. (2014). Progress in green polymer composites from lignin for multifunctional applications: A review. ACS Sustainable Chemistry and Engineering, 2(5), 1072 1092. https://doi.org/10.1021/sc500087z

Tosi, P., van Klink, G. P. M., Celzard, A., Fierro, V., Vincent, L., de Jong, E., \& Mija, A. (2018). Auto-Crosslinked Rigid Foams Derived from Biorefinery Byproducts. ChemSusChem, 11(16), 2797-2809. https://doi.org/10.1002/cssc.201800778

Ullah, A., \& Wu, J. (2013). Feather Fiber-Based Thermoplastics: Effects of Different Plasticizers on Material

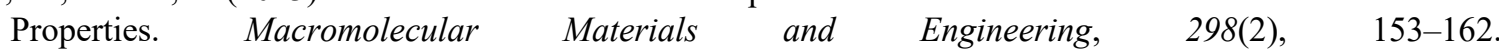
https://doi.org/10.1002/mame.201200010

Van Zandvoort, I., Wang, Y., Rasrendra, C. B., Van Eck, E. R. H., Bruijnincx, P. C. A., Heeres, H. J., \& Weckhuysen, B. M. (2013). Formation, molecular structure, and morphology of humins in biomass conversion: Influence of feedstock and processing conditions. ChemSusChem, 6(9), 1745-1758. https://doi.org/10.1002/cssc.201300332

Wallenberger, F., \& Weston, N. (2004). Natural Fibers, Plastics and Composites. Springer Science+Business Media.

Wang, B., Yang, W., McKittrick, J., \& Meyers, M. A. (2016). Keratin: Structure, mechanical properties, occurrence in biological organisms, and efforts at bioinspiration. Progress in Materials Science, 76, 229318. https://doi.org/10.1016/j.pmatsci.2015.06.001

Wang, H., Pu, Y., Ragauskas, A., \& Yang, B. (2019). From lignin to valuable products-strategies, challenges, and $\begin{array}{llll}\text { prospects. } & \text { Bioresource } \quad \text { Technology, 2018), 449-461. }\end{array}$ https://doi.org/10.1016/j.biortech.2018.09.072

Wang, J., Hao, S., Luo, T., Yang, Q., \& Wang, B. (2016). Development of feather keratin nanoparticles and investigation of their hemostatic efficacy. Materials Science and Engineering: C, 68, 768-773. https://doi.org/10.1016/j.msec.2016.07.035

Wrześniewska-Tosik, K., Szadkowski, M., Marcinkowska, M., \& Pałczyńska, M. (2012). Chicken feathercontaining composite non-wovens with barrier properties. Fibres and Textiles in Eastern Europe, Vol. 96, pp. $96-100$.

Xu, H., Cai, S., Xu, L., \& Yang, Y. (2014). Water-Stable Three-Dimensional Ultrafine Fibrous Scaffolds from Keratin for Cartilage Tissue Engineering. Langmuir, 30(28), 8461-8470. https://doi.org/10.1021/la500768b

Yang, J., Ching, Y. C., \& Chuah, C. H. (2019). Applications of Lignocellulosic Fibers and Lignin in Bioplastics: A Review. Polymers, 11(5), 751. https://doi.org/10.3390/polym11050751

Yang, Y., \& Reddy, N. (2013). Utilizing discarded plastic bags as matrix material for composites reinforced with chicken feathers. Journal of Applied Polymer Science, 130(1), 307-312. https://doi.org/10.1002/app.39173

Yin, Q., Yang, W., Sun, C., \& Di, M. (2012). Preparation and properties of lignin-epoxy resin composite. BioResources, 7(4), 5737-5748. https://doi.org/10.15376/biores.7.4.5737-5748

Yin, X., Li, F., He, Y., Wang, Y., \& Wang, R. (2013). Study on effective extraction of chicken feather keratins and their films for controlling drug release. Biomaterials Science, 1(5), 528. https://doi.org/10.1039/c3bm00158j

Zhan, M., \& Wool, R. P. (2016). Mechanical properties of composites with chicken feather and glass fibers. Journal of Applied Polymer Science, 133(45). https://doi.org/10.1002/app.44013

\section{Copyrights}

Copyright for this article is retained by the author(s), with first publication rights granted to the journal.

This is an open-access article distributed under the terms and conditions of the Creative Commons Attribution license (http://creativecommons.org/licenses/by/4.0/). 